Guest Editorial, part of a Special Feature on Effects of Roads and Traffic on Wildlife Populations and Landscape Function

\title{
Effects of Roads and Traffic on Wildlife Populations and Landscape Function: Road Ecology is Moving toward Larger Scales
}

\author{
$\underline{\text { Rodney van der Ree }}^{1}, \underline{\text { Jochen A. G. Jaeger }}^{2}, \underline{\text { Edgar A. van der Grift }}^{3}$, and Anthony P. Clevenger ${ }^{4}$
}

\begin{abstract}
Road ecology has developed into a significant branch of ecology with steady growth in the number of refereed journal articles, books, conferences, symposia, and "best practice" guidelines being produced each year. The main objective of this special issue of Ecology and Society is to highlight the need for studies that document the population, community, and ecosystem-level effects of roads and traffic by publishing studies that document these effects. It became apparent when compiling this special issue that there is a paucity of studies that explicitly examined higher order effects of roads and traffic. No papers on landscape function or ecosystem-level effects were submitted, despite being highlighted as a priority for publication. The 17 papers in this issue, from Australia, Canada, the Netherlands, and USA, all deal to some extent with either population or community-level effects of roads and traffic. Nevertheless, many higher order effects remain unquantified, and must become the focus of future studies because the complexity and interactions among the effects of roads and traffic are large and potentially unexpected. An analysis of these complex interrelations requires systematic research, and it is necessary to further establish collaborative links between ecologists and transportation agencies. Many road agencies have "environmental sustainability" as one of their goals and the only way to achieve such goals is for them to support and foster long-term and credible scientific research. The current situation, with numerous smallscale projects being undertaken independently of each other, cannot provide the information required to quantify and mitigate the negative effects of roads and traffic on higher levels. The future of road ecology research will be best enhanced when multiple road projects in different states or countries are combined and studied as part of integrated, well-replicated research projects.
\end{abstract}

Key Words: animal movement; animal-vehicle collisions; barrier effect; ecological threshold; gene flow; habitat fragmentation; mitigation; population viability analysis; road ecology; road-effect zone; traffic mortality; traffic noise; traffic volume; transportation planning

\section{INTRODUCTION}

Humans are responsible for the current unprecedented rate of biodiversity loss across the globe with climate change, pollution, and the loss, fragmentation, and degradation of habitat being the major drivers of extinction (Vitousek et al. 1997). Roads and other linear infrastructure are a major cause of habitat loss, fragmentation, and degradation and are ubiquitous in most landscapes around the world. Worldwide, there are already an estimated 750 million vehicles travelling on approximately 50 million $\mathrm{km}$ of public road ( $\mathrm{T}$. Langton, personal communication), and the road network and traffic volumes are still increasing, particularly in eastern Europe, China, India, and Latin America.

Linear infrastructure is important for society because it provides connectivity for people. However, linear infrastructure also exerts significant negative effects on adjacent habitats, wildlife populations, communities, and ecosystems. Research about the ecological effects of roads and traffic on the natural environment began in 1925 when Dayton Stoner documented the 225 traffickilled vertebrates from 29 species that he observed during a 632 mile trip in Iowa, USA (Stoner 1925).

${ }^{1}$ University of Melbourne, ${ }^{2}$ Concordia University Montréal, Department of Geography, Planning and Environment, Quebec, Canada, ${ }^{3}$ Alterra, Wageningen UR, Netherlands, ${ }^{4}$ Western Transportation Institute, Montana State University, USA 
The term "road ecology" was first used in German ("Straßenökologie") in 1981 (Ellenberg et al.), and was later translated into English by Forman et al. (2003) for their book Road Ecology: Science and Solutions. Since the mid 1990s, there has been a rapid increase in the number of studies, publications, and symposia, particularly from Europe, North America, and Australia. These include major national and international reports and best practice guidelines (Iuell et al. 2003, Trocmé et al. 2003, National Research Council 2005, Clevenger and Huijser 2009), regular dedicated conferences such as the biennial International Conference on Ecology and Transportation (ICOET), Infra-Eco Network of Europe (IENE), and symposia and special issues of peer-reviewed journals, e.g., Biological Conservation (Mader 1990), Conservation Biology (Hourdequin 2000), GAIA (Jaeger et al. 2005), and Naturschutz and Landschaftsplanung (Roedenbeck and Jaeger 2006).

The overall aim of road ecology research is to quantify the ecological effects of roads, with the ultimate aim of avoiding, minimizing, and compensating for their negative impacts on individuals, populations, communities, and ecosystems. This research has demonstrated the numerous and diverse effects of roads and traffic on plants and animals, with most studies focusing at the level of the individual animal. These effects include the loss and fragmentation of habitat, increased rates of wildlife mortality because of collision with vehicles, alterations to light, moisture and wind regimes due to the creation of edges, pollution from traffic, e.g., light, noise, and chemical, and facilitating the spread and dispersal of weeds and feral animals. Roads also affect the aesthetic and recreational quality of landscapes for humans (Di Giulio and Holderegger 2009). Consequently, roads have been described as the single most destructive element in the process of habitat fragmentation (Noss 1993) and their ecological effects are considered "the sleeping giant of biological conservation" (Forman 2002:viii).

Understanding the impacts of roads and traffic at higher levels is necessary for a number of good reasons. Most governments have agreed that conservation of biodiversity is important and therefore road agencies must endeavor to ensure that they are contributing to achieving this goal. Counting the number of dead animals on the side of the road or measuring the size of the ecological road- effect zone will not, by itself, inform whether roads and vehicles are endangering the existence of populations or species. The important parameter must be the long-term viability of adjacent populations, and this requires data on the sizes of the populations, vital rates, and level of connectivity among subpopulations. Similarly, a critical question when evaluating mitigation works is the extent to which populations have become more viable, and whether they are now sufficiently viable, not simply how many animals pass through an underpass (van der Ree et al. 2007). The extent to which the results from the numerous local studies can be extrapolated to larger spatial and temporal scales is unknown. Therefore, an important next step is to evaluate how the density and configuration of entire road networks affect the functional relationships within and among ecosystems at the landscape scale. Answers to this question will inform cumulative environmental assessments and transportation planning (Roedenbeck et al. 2007). Roads also affect humans in a range of ways but little research on this topic has been completed (Di Giulio and Holderegger 2009).

Reducing the negative effects of roads and traffic will only be possible if more dialogue is achieved between the scientific community and the planners and political decision makers (Fig. 1). The majority of people in the world live in cities and increasingly, their encounters with wildlife involve animals that have died after collision with vehicles. Novel approaches to engage the public, and hence, governments, are required. A recent example was an award-winning exhibition in the Whyte Museum in Banff, Alberta, Canada in 2006 of images of wildlife using the now famous overpasses and underpasses in Banff National Park. A second example was a creative arts competition as part of the IENE 2010 conference for Hungarian school children to portray the conflict, and solutions, between roads and wildlife (Fig. 2).

\section{ABOUT THIS ISSUE: THE EFFECTS OF ROADS AND TRAFFIC ON POPULATIONS, COMMUNITIES, AND ECOSYSTEMS}

The two main objectives of this special issue of Ecology and Society were to (1) highlight the need for studies that document the population, community, and ecosystem-level effects of roads and traffic, and (2) publish studies that document 
Fig. 1. Society's ability to address the negative effects of road networks on wildlife populations and ecosystems depends on the perception of the ecological effects and risks. As the perception of the effects by society has been severely limited (as indicated by the dotted line), alternative approaches may be required that would be based on more indirect indicators of ecological risk and on the precautionary principle.

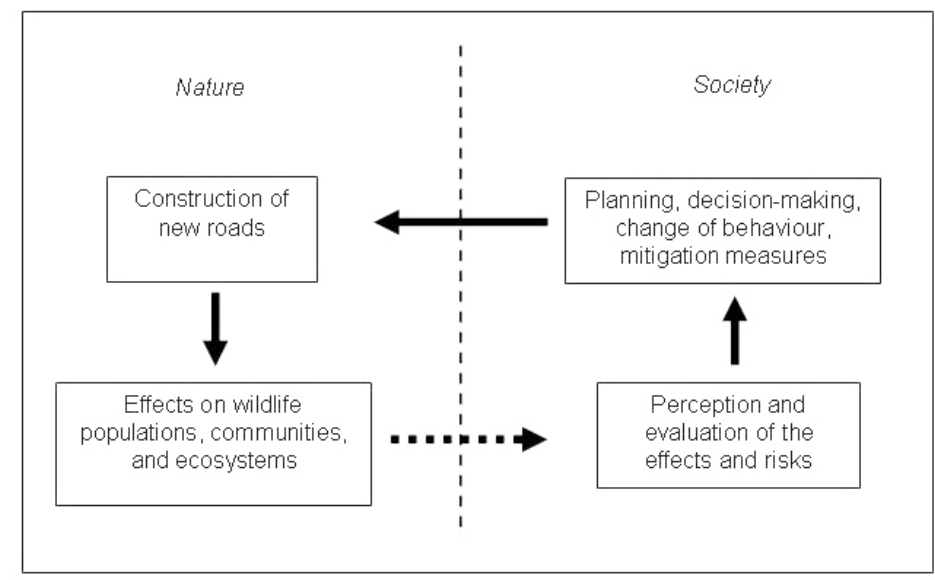

these effects. The special issue consists of 17 papers from four countries, i.e., Australia, Canada, the Netherlands, and U.S.A., that all deal to some extent with either population or community-level effects of roads and traffic. It became apparent when compiling the special issue that there is a paucity of road ecology studies that explicitly examined higher order effects of roads. No papers on landscape function or ecosystem-level effects were submitted, despite being highlighted as a priority for publication.

The special issue begins with a synthesis paper (Fahrig and Rytwinski 2009) and ends with an insight paper (Simmons et al. 2010). The synthesis is an appropriate first paper because it assesses the widely held assertion that "there are very few studies that assess the population-level effects of roads and traffic." The assertion was found to be partly true and partly false; the authors located 79 studies that provide data on population-level effects (abundance and density) but found that in most cases, the population-level effect was 'hidden' in many of the papers reviewed. Nevertheless, Fahrig and Rytwinski (2009) found that overwhelmingly, roads and traffic had a negative effect on animal abundance, with negative effects outnumbering positive effects by a factor of five. The final paper in the special issue reviews some of the genetic methods used in road ecology and provides an insight into how conservation genetics can be better utilized in future studies. Simmons et al. (2010) argue that conservation genetics is a rapidly evolving field and that many of the widely perceived limitations to the use of genetics are either misconceptions or no longer apply. They conclude with strong recommendations that genetic approaches be combined with field studies to increase the inferential strength of whichever study design is adopted (sensu Roedenbeck et al. 2007).

The road-effect zone is the distance from the edge of the road over which significant ecological effects can be detected (Forman and Alexander 1998). Eigenbrod et al. (2009) quantified threshold effects of a motorway on anuran populations in Canada, and Bissonette and Rosa (2009) investigated the effects of a motorway on the composition and abundance of a small-mammal community in the deserts of Utah, USA. Eigenbrod et al. (2009) were the first to quantify the road-effect zone on the species richness and relative abundance of anurans, and found strong negative effects for four of seven species, extending $250-1000 \mathrm{~m}$ from the road edge. They conclude that although most anurans are likely to have reduced abundances near motorways, the extent and cause of this relationship will vary among species (Eigenbrod et al. 2009). In contrast, Bissonette and Rosa (2009) found that roadside vegetation in desert environments often provides 
Fig. 2. Runner up of the "On Dangerous Roads" Competition organized by Varangy Akciócsoport Egyesület for the 2010 Infra-Eco Network of Europe Conference showing an overpass used by wildlife. An ongoing project in the Netherlands is studying the effectiveness of an overpass for amphibians, in combination with fences along the road. This overpass is equipped with a cascading series of small ponds fed with water pumped into the highest pond in the center of the overpass.

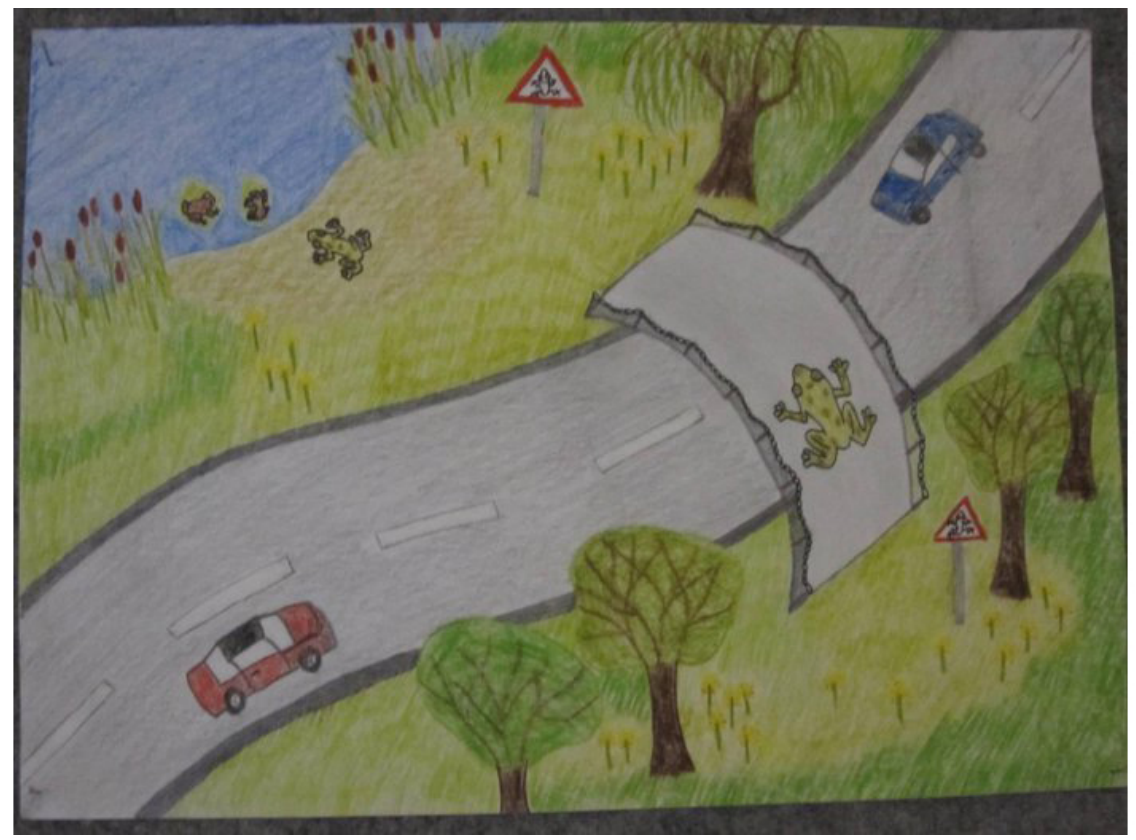

suitable habitat for small mammals. Only 2 of 13 species of small mammals were never captured near roads, and the remaining 11 species' numbers were either similar or more abundant near the road than further away.

Vegetation adjacent to roads often provides habitat (e.g., Bissonette and Rosa 2009), and in some landscapes, even the majority of habitat (van der Ree and Bennett 2003). Wildlife that use this habitat will experience traffic noise and may be affected by it. Anthropogenic noise has the potential to severely disrupt the communication of species by acoustic interference or masking. Three studies in this special issue investigate this effect on frogs and birds. Parris and Schneider (2008) found that the Grey Shrikethrush (Colluricincla harmonica) sang at a higher frequency in areas with traffic noise than the Grey Fantail (Rhipidura fuliginosa) and that the probability of detecting either species declined substantially with increasing traffic noise and traffic volume. The effects of traffic noise on frogs were assessed by Parris et al. (2009) in an urban landscape in southeast Australia and by Hoskin and Goosem (2010) in tropical rainforest in northeastern Australia. One species of urban frog in and around Melbourne called at a higher pitch in traffic noise, while the second species studied may also call at a higher pitch, but more data is required to be sure (Parris et al. 2009). Litoria rheocola in tropical rainforest also called at a higher pitch when closer to the road, as well as calling at a higher rate when near roads (Hoskin and Goosem 2010). The abundance of some species of rainforest frogs was also lower near roads.

A significant proportion of the road ecology literature is focused on evaluating the use and effectiveness of mitigation measures that aim to restore connectivity for wildlife or reduce rates of animal-vehicle collisions. A review presented at the ICOET conference in 2007 concluded that most studies in the scientific and grey literature had focused almost exclusively on documenting rates of use of wildlife passages, and that few had explicitly evaluated the effectiveness of mitigation measures 
at enhancing population viability (van der Ree et al. 2007). In this special issue, five papers have addressed the topic of mitigation of road effects on wildlife in differing perspectives. Thorne et al. (2009) highlight the importance of landscape-scale planning to better integrate the needs of wildlife into regional transportation plans. Using two examples from California, USA, they show how road projects can benefit financially and ecologically when road agencies and conservation groups collaborate early in the planning stages. Approximately $1-2$ million mammal-vehicle collisions occur annually in North America, causing in excess of 200 human fatalities and over one billion U.S. dollars in property damage each year (references in Huijser et al. 2009). Huijser et al. (2009) reviewed the effectiveness and cost of 13 measures considered effective at reducing collisions with large ungulates and found that for many sections of road, the effectiveness, measured as money saved, exceeds the costs to install the mitigation. The results of their cost-benefit model suggests that there must be many locations in North America where the mitigation measures are costeffective, and thereby would save society money and improve road safety for humans and wildlife if implemented more often. At a smaller spatial scale, Grosman et al. (2009) combined real data on the movement of moose (Alces alces) with agent-based computer simulations to investigate if the removal of salt pools or their relocation from adjacent to the highway to $100-1500$ m away from the road would result in fewer moose-vehicle collisions. Their model predicted that the removal of salt pools from near the edge of the highway would result in an almost $50 \%$ reduction in moose-vehicle collisions (Grosman et al. 2009).

The viability of populations adjacent to wildlife crossing structures is one of the fundamental measures of success of mitigation (van der Ree et al. 2007). Two papers in this special issue explicitly investigated the increase in the viability of a population of wildlife after mitigation (Taylor and Goldingay 2009, van der Ree et al. 2009). Taylor and Goldingay (2009) used population modeling to assess the viability of the Greater Glider (Petauroides volans) in Brisbane, a rapidly urbanizing area of Australia. They concluded that even a relatively low rate of dispersal across the road was sufficient to substantially reduce the risk of extinction of the smaller subpopulation isolated by the road. Similarly, van der Ree et al. (2009) used population viability modeling to assess the effectiveness of under-road tunnels installed in 1985 to restore connectivity for the critically endangered Mountain Pygmy-possum (Burramys parvus; Mansergh and Scotts 1989). They found that the tunnels reduced, but did not completely eliminate the negative effect of the road, with the density of the population affected by the road still $15 \%$ lower than a comparable undivided population nearby (van der Ree et al. 2009).

The majority of studies that assess the use of wildlife crossing structures have utilized two primary methods to detect and record wildlife passage, namely remotely triggered cameras, and/or the detection of tracks in a suitable substrate (van der Ree et al. 2007). Clevenger and Sawaya (2010) have used the suggestions of Simmons et al. (2010) and tested the feasibility of a noninvasive genetic sampling approach to identify the species as well as the sex, individual, and relatedness of different individuals using the crossing structure. The technique, if successful, would be applied at a larger scale to determine the level of genetic fragmentation and natural and anthropogenic factors influencing gene flow. They tested their approach on Black Bears (Ursus americanus) and Grizzly Bears ( $U$. arctos) at two underpasses in Banff National Park. Hair was collected from $90 \%$ of crossing events (determined from cameras), and $70 \%$ of hair samples had sufficient DNA for extraction, resulting in the identification of five individual bears at each underpass, and highlighting the potential of this method for population-level analysis of the efficacy of wildlife crossing structures (Clevenger and Sawaya 2010).

There is still a paucity of data on the behavior and movement of animals near roads. Bouchard et al. (2009) evaluated the behavioral response of the Northern Leopard Frog (Rana pipiens), a species known to be negatively affected by roads and traffic. They studied the movement of frogs during their spring migration and also undertook short distance translocations of migrating frogs and found frogs near roads with more traffic took longer to move and tended to deviate more from straight-line movements when released near roads (Bouchard et al. 2009). The combination of the Northern Leopard Frog's apparent inability to avoid roads and their slow rate of movement make them highly vulnerable to road mortality. The second study in this special issue on the movement behavior of wildlife near roads was for the Squirrel Glider (Petaurus norfolcensis) in southeast Australia (van der Ree et al. 2010). The authors found that the size 
of the gap in the canopy was the primary determinant of the rate of crossing in their study, with similar rates of crossing across the dual-roadway with tall trees in the median and across single-lane roads. In this study, traffic volume, i.e., approximately 5000 vehicles per day per roadway of which about $25 \%$ occurs at night when the gliders are active, did not appear to greatly influence crossing rates.

The traffic volume on minor roads is expected to continue to increase in areas with high human population densities because existing motorways are nearing capacity and the minor roads are expected to accommodate the excess flows (references in van Langevelde and Jaarsma 2009). Traffic calming is a regional planning approach to concentrate these flows onto a few roads, and ensure low-volume and low-speed roads are maintained. The conclusions of population viability modeling suggest that the results are species specific and depend upon the size of the traffic-calmed area as well as the area and quality of habitat (van Langevelde and Jaarsma 2009).

\section{ROAD ECOLOGY: THE ROAD AHEAD}

The research presented in this special feature shows that road ecology is moving toward larger scales. However, it also became evident while compiling this special issue that many higher order, e.g., population, community, ecosystem, or landscapelevel, effects remain unquantified. These higher order effects must become the focus of future studies because the complexity and interactions among the effects of roads and traffic are large and potentially unexpected. An analysis of these complex interrelations requires systematic research. Therefore, a promising avenue to further develop the field of road ecology is to establish collaborative links with road and transportation agencies. Experience shows that the level of engagement with each local, state, or national road agency depends largely on the presence of interested people, rather than an institutionalized approach to environmental matters. However, institutional mandates are important as they are often a precondition for interested people to spend their efforts during work hours on these issues. Many road agencies have "environmental sustainability" as one of their goals and the only way to achieve such goals is for them to support and foster long-term and credible scientific research. Every road project is essentially an experiment and when combined with other road projects, they become replicated. The challenge we face as researchers is to (1) use good scientific approaches to design studies that are scientifically robust and maximize the individual value of each road project within a larger experimental scope; (2) ensure our research is applied and has tangible value for road agencies and for ecological outcomes; (3) address the higher order effects of roads, traffic, and mitigation measures.

This special feature demonstrates that the emerging field of road ecology is confronted with many important unanswered questions. Research needs to address large spatial and temporal scales that are not compatible within most postgraduate programs, i.e., single $\mathrm{MSc}$ or $\mathrm{PhD}$ theses, or short-term research contracts. The synergistic effects of roads and other factors that operate simultaneously, e.g., agricultural intensification and increased urbanization, have rarely been investigated. However, empirical studies are limited by the delayed response of wildlife to many environmental changes, i.e., there is an extinction debt such that wildlife populations will continue to decline for many years, in the order of decades, before they will reach a new equilibrium (Tilman et al. 1994, Findlay and Bourdages 2000). This lack of knowledge is often used as a justification to build more roads by arguing that not enough is known and more research is needed before road construction may slow down. This constitutes a "fragmentation spiral" (Jaeger 2002), because research has been unable to catch up with the ecological effects of the rapid increase in road densities. This situation is contrary to the precautionary principle and flies in the face of the principles of sustainability. The use of computer models may help overcome these limitations. For example, simulation models have demonstrated that there are thresholds in the effects of road density on the viability of wildlife populations above which populations are prone to extinction (Jaeger and Holderegger 2005, Frair et al. 2008). In addition, a research approach is required that will address the remaining uncertainties that to a large degree are irreducible, e.g., through building on the precautionary principle (e.g., Jaeger 2002). This would open up promising new lines of action for landscape management. For example, the German Federal Environment Agency recently suggested that region-specific limits to control landscape fragmentation should be introduced (Penn-Bressel 2005). 
With this issue, we hope to contribute to the field of road ecology and to highlight both its appealing theoretical insights and its high practical relevance. Most importantly, we hope that this special issue will inspire further research in road ecology at the scale of populations, communities, and ecosystems. We are looking forward to these exciting research studies to come.

Responses to this article can be read online at: http://www.ecologyandsociety.org/voll6/iss 1/art48/ responses/

\section{Acknowledgments:}

We sincerely thank all authors and the many reviewers who have contributed to this special feature and Carl Folke, Adele Mullie, and Jennifer Miner from Ecology and Society for making this special feature possible.

\section{LITERATURE CITED}

Bissonette, J. A., and S. A. Rosa. 2009. Road zone effects in small-mammal communities. Ecology and Society 14(1): 27. [online] URL: http://www.e cologyandsociety.org/vol14/iss 1/art27/.

Bouchard, J., A. T. Ford, F. Eigenbrod, and L. Fahrig. 2009. Behavioral response of northern leopard frogs (Rana pipens) to roads and traffic: implications for population persistence. Ecology and Society 14(2): 23. [online] URL: http://www.e cologyandsociety.org/vol14/iss2/art23/.

Clevenger, A. P., and M. P. Huijser. 2009. Handbook for design and evaluation of wildlife crossing structures in North America. Department of Transportation, Federal Highway Administration, Washington, D.C., USA.

Clevenger, A. P., and M. A. Sawaya. 2010. Piloting a non-invasive genetic sampling method for evaluating population-level benefits of wildlife crossing structures. Ecology and Society 15(1): 7. [online] URL: http://www.ecologyandsociety.org/vol15/ iss1/art7/.
Di Giulio, M., and R. Holderegger. 2009. Effects of habitat and landscape fragmentation on humans and biodiversity in densely populated landscapes. Journal Of Environmental Management 90:2959-2968.

Eigenbrod, F., S. J. Hecnar, and L. Fahrig. 2009. Quantifying the road-effect zone: threshold effects of a motorway on anuran populations in Ontario, Canada. Ecology and Society 14(1): 24. [online] URL: http://www.ecologyandsociety.org/vol14/iss1/ $\underline{\operatorname{art} 24 / .}$.

Ellenberg, H., K. Müller, and T. Stottele. 1981. Straßen-Ökologie: Auswirkungen von Autobahnen und Straßen auf Ökosysteme deutscher Landschaften. Ökologie und Straße. Bonn, Germany: Broschürenreihe der deutschen Straßenliga, Ausgabe 3:19-122.

Fahrig, L., and T. Rytwinski. 2009. Effects of roads on animal abundance: an empirical review and synthesis. Ecology and Society 14(1): 21. [online] URL: http://www.ecologyandsociety.org/vol14/iss1/ $\underline{\operatorname{art} 21 /}$.

Findlay, C. S., and J. Bourdages. 2000. Response time of wetland biodiversity to road construction on adjacent lands. Conservation Biology 14:86-94.

Forman, R. T. T. 2002. Foreword. Pages vii - $\mathrm{x}$ in K. J. Gutzwiller, editor. Applying landscape ecology in biological conservation. Springer, New York, New York, USA.

Forman, R. T. T., and L. E. Alexander. 1998. Roads and their major ecological effects. Annual Review of Ecology and Systematics 29:207-231.

Forman, R. T. T., D. Sperling, J. A. Bissonette, A. P. Clevenger, C. D. Cutshall, V. H. Dale, L. Fahrig, R. France, C. R. Goldman, K. Heanue, J. A. Jones, F. J. Swanson, T. Turrentine, and T. C. Winter. 2003. Road Ecology. Science and Solutions. Island Press, Washington, D.C., USA.

Frair, J. L., E. H. Merrill, H. L. Beyer, and J. M. Morales. 2008. Thresholds in landscape connectivity and mortality risks in response to growing road networks. Journal Of Applied Ecology 45:1504-1513.

Grosman, P. D., J. A. G. Jaeger, P. M. Biron, C. Dussault, and J.-P. Ouellet. 2009. Reducing moosevehicle collisions through salt pool removal and displacement: an agent-based modelling approach. 
Ecology and Society 14(2): 17. [online] URL: http: //www.ecologyandsociety.org/vol14/iss2/art17/.

Hoskin, C. J., and M. W. Goosem. 2010. Road impacts on abundance, call traits, and body size of rainforest frogs in northeast Australia. Ecology and Society 15(3): 15. [online] URL: http://www.ecolog yandsociety.org/vol15/iss3/art15/.

Huijser, M. P., J. W. Duffield, A. P. Clevenger, R. J. Ament, and P. T. McGowen. 2009. Cost-benefit analyses of mitigation measures aimed at reducing collisions with large ungulates in the United States and Canada: a decision support tool. Ecology and Society 14(2): 15. [online] URL: http://www.ecolog yandsociety.org/vol14/iss2/art15/.

Hourdequin, M., editor. 2000. The ecological effects of roads. Special issue of Conservation Biology 14(1):16-94.

Iuell, B., G. J. Bekker, R. Cuperus, J. Dufek, G. Fry, C. Hicks, V. Hlavác, V. Keller, B. Rosell, T. Sangwine, N. Tørsløv, and B. 1. M. Wandall. 2003. COST 341 - Wildlife and traffic: a European handbook for identifying conflicts and designing solutions. KNNV Publishers, Brussels, Belgium.

Jaeger, J. A. G. 2002. Landschaftszerschneidung. Eine transdisziplinäre Studie gemäß dem Konzept der Umweltgefährdung. [Translation: Landscape fragmentation. A transdisciplinary study according to the concept of environmental threat.] Verlag Eugen Ulmer, Stuttgart, Germany.

Jaeger, J. A. G., S. Grau, and W. Haber, editors. 2005. Landscape fragmentation due to transportation infrastructure and urban development: from recognition of the problem to implementation of measures. Special issue of GAIA 14(2):98-185.

Jaeger, J. A. G., and R. Holderegger. 2005. Schwellenwerte der Landschaftszerschneidung. [Translation: Thresholds of landscape fragmentation.] GAIA 14:113-118.

Mader, H.-J., editor. 1990. Survival and dispersal of animals in cultivated landscapes. Special issue of Biological Conservation 54(3):167-290.

Mansergh, I. M., and D. J. Scotts. 1989. Habitat continuity and social organisation of the mountain pygmy-possum restored by tunnel. Journal of Wildlife Management 53:701-707.
National Research Council. 2005. Assessing and managing the ecological impacts of paved roads. L. Gunderson, A. Clevenger, A. Cooper, V. Dale, L. Evans, G. Evink, L. Fahrig, K. Haynes, W. Kober, S. Lester, K. Redford, M. Strand, P. Wagner, and J. Yowell, committee members. National Academies Press, Washington, D.C., USA.

Noss, R. F. 1993. Wildlife corridors. Pages 43-68 in D. S. Smith and P. C. Hellmund, editors. Ecology of Greenways. University of Minneapolis Press, Minneapolis, Minnesota, USA.

Parris, K. M., and A. Schneider. 2008. Impacts of traffic noise and traffic volume on birds of roadside habitats. Ecology and Society 14(1): 29. [online] URL: http://www.ecologyandsociety.org/vol14/iss1/ $\underline{\operatorname{art} 29 / .}$

Parris K. M., M. Velik-Lord, and J. M. A. North. 2009. Frogs call at a higher pitch in traffic noise. Ecology and Society 14(1): 25. [online] URL: http: //www.ecologyandsociety.org/vol14/iss1/art25/.

Penn-Bressel, G. 2005. Begrenzung der

Landschaftszerschneidung bei der Planung von Verkehrswegen. [Translation: Limiting landscape fragmentation and the planning of transportation routes.] GAIA 14:130-134.

Roedenbeck, I. A., L. Fahrig, C. S. Findlay, J. E. Houlahan, J. A. G. Jaeger, N. Klar, S. KramerSchadt, and E. A. van der Grift. 2007. The Rauischholzhausen agenda for road ecology. Ecology and Society 12(1): 11. [online] URL: http: //www.ecologyandsociety.org/vol12/iss1/art11/ .

Roedenbeck, I. A., and J. A. G. Jaeger, editors. 2006. Road ecology research. [Articles in English and German.] Special issue of Naturschutz und Landschaftsplanung 38(10-11):293-356.

Simmons, J., P. Sunnucks, A. C. Taylor, and R. van der Ree. 2010. Beyond road-kill, radiotracking, recapture and $\mathrm{F}_{\mathrm{ST}}$ - a review of some genetic methods to improve understanding of the influence of roads on wildlife. Ecology and Society 15(1): 9. [online] URL: http://www.ecologyandsociety.org/vol15/ iss1/art9/.

Stoner, D. 1925. The toll of the automobile. Science 61:56-57. 
Taylor, B. D., and R. Goldingay. 2009. Can roadcrossing structures improve population viability of an urban gliding mammal? Ecology and Society 14 (2): 13. [online] URL: www.ecologyandsociety.org/ vol14/iss2/art13/.

Thorne, J. H., P. R. Huber, E. H. Girvetz, J. Quinn, and M. C. McCoy. 2009. Integration of regional mitigation assessment and conservation planning. Ecology and Society 14(1): 47. [online] URL: http: //www.ecologyandsociety.org/vol14/iss1/art47/.

Tilman, D., R. M. May, C. L. Lehman, and M. A. Nowak. 1994. Habitat destruction and the extinction debt. Nature 371:65-66.

Trocmé, M., S. Cahill, J. G. de Vries, H. Farrall, L. Folkeson, G. Fry, C. Hicks, and J. Peymen. 2003. COST 341 - Habitat fragmentation due to transportation infrastructure: the European review. Publications Office of the European Union, Luxembourg.

van der Ree, R., and A. F. Bennett. 2003. Home range of the squirrel glider Petaurus norfolcensis in a network of linear habitats. Journal of Zoology (London) 259:327-336.

van der Ree, R., S. Cesarini, P. Sunnucks, J. L. Moore, and A. C. Taylor. 2010. Large gaps in canopy reduce road crossing by a gliding mammal Ecology and Society 15(4): 35. [online] URL: http: //www.ecologyandsociety.org/vol15/iss4/art35/.

van der Ree, R., D. Heinze, M. McCarthy, and I. Mansergh. 2009. Wildlife tunnel enhances population viability. Ecology and Society 14(2): 7. [online] URL: http://www.ecologyandsociety.org/vol14/ iss $2 / \operatorname{art} 7 /$.

van der Ree, R., E. A. van der Grift, C. Mata, and F. Suarez. 2007. Overcoming the barrier effect of roads - how effective are mitigation strategies? An international review of the effectiveness of underpasses and overpasses designed to increase the permeability of roads for wildlife. Pages 423-431 in C. L. Irwin, D. Nelson, and K. P. McDermott, editors. International Conference on Ecology and Transportation. Center for Transportation and The Environment, North Carolina State University, Raleigh, North Carolina, Little Rock, Arkansas, USA. van Langevelde, F., and C. F. Jaarsma. 2009. Modeling the effect of traffic calming on local animal population persistence. Ecology and Society 14(2): 39. [online] URL: http://www.ecologyandso ciety.org/vol14/iss2/art39/.

Vitousek, P. M., H. A. Mooney, J. Lubchenco, and J. M. Melillo. 1997. Human domination of Earth's ecosystems. Science 277:494-499. 